\title{
CUANTIFICATION OF LAND DEGRADATION SENSITIVITY AREAS IN ROMANIA USING EUROPEAN DISMED DATA
}

\author{
Remus Prăvălie ${ }^{1}$
}

Key words: land degradation, desertification, sensitivity, DISMED, area, Romania.

\begin{abstract}
Land degradation is presently an important environmental issue in many regions of the Globe, including Central South-Eastern Europe, where Romania is located. This study aims to quantify areas with significant sensitivity to degradation at national level, based on data provided by the European Environment Agency, obtained relatively recently through the DISMED project (Desertification Information System for the Mediterranean) in the Mediterranean and Central South-Eastern regions of Europe. The analysis is based on extracting SDI index (Desertification Sensitivity Index) information for the country's entire territory, as well as for certain major regional, natural (landforms) and anthropogenic (counties) units. Thus, the areas corresponding to the most representative classes for land degradation potential in Romania were extracted, i.e. the ones with moderate and high sensitivity. The study also attempts to differentiate the degradation / desertification processes spatially, by delimiting drylands, for which the land degradation process is considered to be equivalent to desertification. The results showed that, at national level, there are $\sim 72000 \mathrm{~km}^{2}$ of lands with moderate and high degradation potential $(30 \%$ of the country's total surface), of which $80 \%\left(\sim 57000 \mathrm{~km}^{2}\right)$ can be classified as sensitive to desertification. It was noticed that most degradation-prone areas are concentrated in the Romanian Plain ( $30000 \mathrm{~km}^{2}$ moderate sensitivity) and the Dobrogea Plateau $\left(\sim 4150 \mathrm{~km}^{2}\right.$ high sensitivity), in terms of the natural criterion, and in Braila $\left(\sim 4200 \mathrm{~km}^{2}\right.$ moderate sensitivity) and Constanta $\left(\sim 3200 \mathrm{~km}^{2}\right.$ high sensitivity) counties, in terms of the anthropogenic one. It was also found that land degradation in these areas corresponds to desertification, considering the existence of dry sub-humid and semi-arid climates, which are components of dryland systems.
\end{abstract}

${ }^{1}$ PhD. student, University of Bucharest, Faculty of Geography, Bucharest, Romania, pravalie_remus@yahoo.com 


\section{Introduction}

In the synergistic context of global climate changes and heavy anthropogenic pressure, the current advanced state of land degradation is a critical global-scale environmental problem. In restrictive climates, this degradation is known as desertification, a process which is defined as "land degradation in arid, semiarid and sub-humid areas resulting from various factors, including climatic variations and human activities", according to the widely known definition of the United Nations Convention to Combat Desertification UNCCD (UNCCD, 1994).

It is therefore unanimously accepted that the desertification process takes place in dryland systems, which fall in the $0.05-0.65 \mathrm{~mm} / \mathrm{mm}$ climate value interval (considering the ratio between multiannual precipitation and evapotranspiration values) (Middleton and Sterberg, 2013), thus not taking into account the extreme dryland class, the hyper-arid climate $(<0.05 \mathrm{~mm} / \mathrm{mm})$. While it is estimated that this phenomenon is currently directly affecting over a third of the Earth's land surface and a population of approximately 250 million people (Reynolds et al., 2007), the population indirectly affected is thought to exceed one billion (Thomas, 1997; Yang, 2010).

Globally, four major regions affected by desertification were identified (the Mediterranean region, Sahel, Mesopotamia and China's loess region) (Dregne, 1976; Dregne, 1986). The main environmental problems identified in these regions are connected to physical (water and wind erosion), chemical (salinization) and biological (soil surface oxidation of organic matter) land degradation, as well as to the loss / degradation of vegetation (and, implicitly, to carbon storage capacity), the soil's organic matter and water infiltration / storage capacity, amplification of atmospheric dust etc. (Dregne, 2002).

In Southern Europe, in the Mediterranean region, although faulty land management and policies are a major cause of environmental deterioration, escalating climate changes recorded over the past decades, especially the ones which determined the intensification of drought phenomena (Xoplaki et al., 2004; Sousa et al., 2011; Philandras et al., 2011), played an essential role in the degradation of natural and anthropogenic systems.

In this context, studies focusing on the analysis of land degradation potential in Southern Europe, based on fundamental biophysical variables, have found that there currently is a high land degradation sensitivity especially in countries such as Spain, Portugal, Italy and Greece, as well as in certain states in South-Eastern Europe, such as Romania and Bulgaria (EEA, 2008). These findings were made possible by the DISMED project (Desertification Information System for the Mediterranean), which was developed by the European Environment Agency for the states included in Annexes IV (Northern 
Mediterranean) and V (Central-South-Eastern Europe) of the UNCCD (EEA, 2008).

The project's results were obtained by applying the ESA principles (Environmental Sensitive Areas to Desertification) of the initial project, MEDALUS (Mediterranean Desertification and Land Use) (Basso et al., 1999; Kosmas et al., 1999), financed by the European Commission in order to analyse desertification-prone areas, based on natural and anthropogenic factors (agricultural land management). Therefore, by using natural variables alone (climate, soil and vegetation characteristics), organized as theme layers such as CQI (Climate Quality Index), SQI (Soil Quality Index), VQI (Vegetation Quality Index), and subsequently processing them by means of geographic information systems, the DISMED results are considered to be a major point of reference for the general assessment of land degradation sensitivity in Europe.

This study attempts to quantify Romanian territories which have a significant degradation potential, based on current geospatial data of the DISMED project, available on the online platform of the European Environment Agency.

\section{Methodology}

In order to spatialize and quantify areas with degradation sensitivity, the data were downloaded from the online platform of the DISMED project, coordinated by the European Environment Agency (EEA, 2008). Four sets of spatial data were used, as well as three sets of raster data corresponding to biophysical variables, and a set of raster data corresponding to the final index of degradation sensitivity.

The biophysical variables, organized under the form of Climate Quality Index (CQI), Soil Quality Index (SQI) and Vegetation Quality Index (VQI), were only used for the mapping of the natural factors (climate, soil, vegetation) based on which the final index was obtained. According to the methodology developed within the DISMED project, the Climate Quality Index was obtained based on the aridity index (computed as the ratio between precipitation and potential evapotranspiration).

The Soil Quality Index was computed based on the geometric mean of four fundamental parameters, which determine soil quality directly or indirectly, i.e. parental material, soil depth, texture and slope. The same principle was applied for the Vegetation Quality Index, computed based on the geometrical mean of four essential parameters of vegetation quality, i.e. erosion protection, resistance to drought, ground coverage and resistance to fire. 
Each indicator group / subgroup was classified and weighted with scores ranging from 1 to 2 , so as to highlight the degradation potential (1 - very low potential, 2 - very high potential). For instance, the aridity index classes (CQI component), i.e. humid climate $(>0.65 \mathrm{~mm} / \mathrm{mm})$, dry sub-humid $(0.5-0.65$ $\mathrm{mm} / \mathrm{mm})$, semi-arid $(0.2-0.5 \mathrm{~mm} / \mathrm{mm})$, arid $(0.05-0.2 \mathrm{~mm})$ and hyper-arid $(<$ $0.05 \mathrm{~mm} / \mathrm{mm}$ ) categories were assigned the scores $1,1.25,1.5,1.75$, and 2 .

Finally, the degradation sensitivity index - SDI (Sensitivity Desertification Index) was computed based on the geometrical mean of the three biophysical factors. The index was classified in five sensitivity categories, i.e. very low (< $1.2)$, low $(1.2-1.3)$, moderate $(1.3-1.4)$, high $(1.4-1.6)$ and very high $(>1.6)$ (EEA, 2008).

The quantification of regions with different degradation sensitivity degrees was done based on the first four categories (the last is not present on Romanian territory), and on the actual analysis of classes 3 and 4 (the most important), which correspond to moderate and high sensitivity. To this end, geostatistical methods were used by means of the ArcGIS 10.1 software, and the spatial units in which sensitive areas were found were of geographical (the main landforms) and anthropogenic (counties) nature.

It is particularly important to mention that this study also attempted to clarify the land degradation / desertification terminology by spatially delimiting the areas sensitive to the two processes as precisely as possible. As according to the UNCCD definition, desertification is the land degradation process typical for drylands, the present paper made use of a current high resolution aridity index (Trabucco and Zomer, 2009), based on which the two processes were differentiated in terms of occurrence potential, i.e. land degradation (in nondryland areas) and desertification (in drylands, defined by the ratio between precipitation and potential evapotranspiration $<0.65 \mathrm{~mm} / \mathrm{mm}$ ).

\section{Results and discussions}

The spatialization of the three biophysical variables on Romanian territory highlighted different sensitivity degrees, depending on the criterion that was considered. According to the Climate Quality Index, areas in the southeast (eastern Romanian Plain, Dobrogea Plateau and the Danube Delta) are the most prone to degradation, as they have the highest mean multiannual climatic water deficit (Fig. 1a), classified as drylands $(<0.65 \mathrm{~mm} / \mathrm{mm})$ from the standpoint of climate aridity recorded in the 1961-1990 period (EEA, 2008).

The Soil Quality Index analysis indicated extensive areas with high degradation potential especially in the western half of the Romanian Plain and in the Getic Plateau (Fig. 1b), due to restrictive soil conditions, such as parental material (friable formations, e.g. clay, sandy formation, alluvium and 
colluviums) or texture (loamy-clayey, clayey-sandy, sandy-clayey, clayey clayey-loamy) (EEA, 2008).

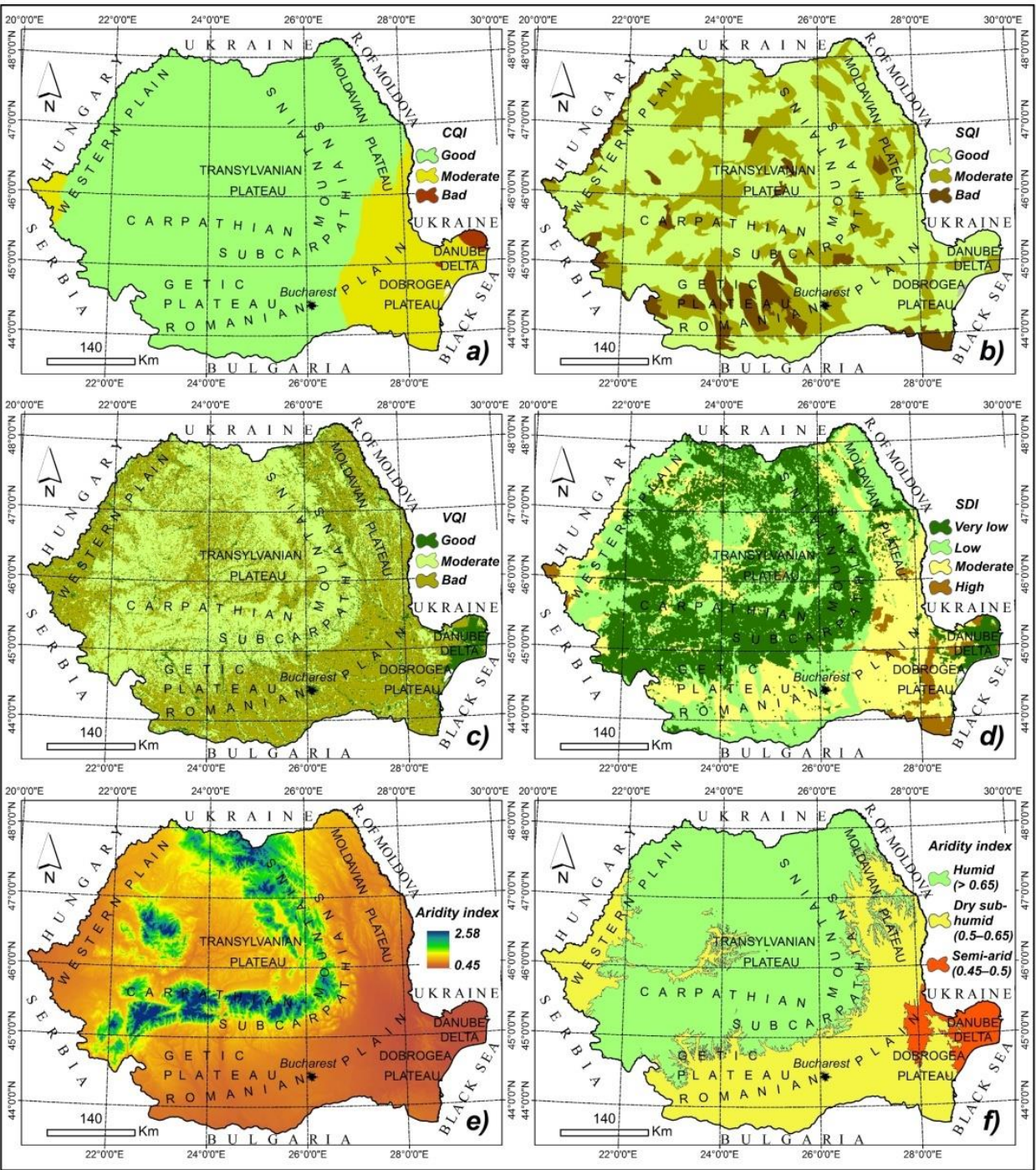

Fig. 1 Spatial representation of the Climate Quality Index - CQI (a), Soil Quality Index SQI (b), Vegetation Quality Index - VQI (c), and of the Sensitivity Desertification Index - SDI (d) in Romania; spatial repartition of the UNEP aridity index values (1950-2000) at national scale, unclassified (e) and classified (f), in order to delimitate dryland areas (with sub-humid and semi-arid climate) 
The Vegetation Quality Index indicated that extra-Carpathians areas are the most prone to degradation (southern and eastern regions, except for the Danube Delta) (Fig. 1c), especially due to the stress drought phenomena generate (typical for these regions), and to the low ground vegetation coverage (EEA, 2008).

The final index (computed as the geometrical mean of the three theme layers) of land degradation sensitivity (called Sensitivity Desertification Index in the DISMED project), mainly highlights extra-Carpathians areas in terms of high sensitivity to this process (Fig. 1d). Thus, classes 3 (moderate sensitivity) and 4 (high sensitivity) of SDI were deemed relevant for the quantitative analysis of the land deterioration potential both at national level and in spatial units of geographic (landforms) and anthropogenic (counties) nature.

However, before performing this analysis, it must be mentioned that, within the DISMED project, the desertification terminology was somewhat improperly used (with the final index) at all European area (corresponding to countries in Annexes IV and V of UNCCD), considering that whether or not the land degradation potential was delimited in dryland systems $(<0.65 \mathrm{~mm} / \mathrm{mm})$ was not taken into account. Thus, based on the principle that desertification occurs exclusively within dryland areas, the terminology must only be used in this particular spatial context. Outside dryland areas (> $0.65 \mathrm{~mm} / \mathrm{mm}$ ), land deterioration characterization must be made by using the term land degradation.

For delimiting the two processes, which are basically different in terms of mechanism intensity, dryland systems were marked by means of an updated UNEP aridity index, which is currently available at the highest spatial resolution (30 arc seconds or $\sim 1 \mathrm{~km}$ at equator) for the entire Globe (Trabucco and Zomer, 2009).

According to this index, the values of which range between 0.45 and 2.58 $\mathrm{mm} / \mathrm{mm}$ at national level (Fig. 1e), dryland systems (areas with semi-arid and dry sub-humid climate in Romania) cover a total area of approximately $104600 \mathrm{~km}^{2}$ $\left(\sim 95560 \mathrm{~km}^{2}\right.$ areas with sub-humid climate and about $9000 \mathrm{~km}^{2}$ areas with semiarid climate), or $44 \%$ of the country's surface (Fig. 1f).

With regard to the quantitative analysis of classes 3 and 4 of the SDI, they total an area of almost $72000 \mathrm{~km}^{2}$ in Romania $\left(\sim 64700 \mathrm{~km}^{2}\right.$ moderate sensitivity land class, $\sim 7100 \mathrm{~km}^{2}$ high potential class), which corresponds to $30 \%$ of the country's surface. Of this total land degradation area, almost $80 \%\left(\sim 57000 \mathrm{~km}^{2}\right)$ is constituted by land desertification ( $24 \%$ of the country's surface), with moderate $\left(\sim 50000 \mathrm{~km}^{2}\right)$ and high $\left(\sim 7000 \mathrm{~km}^{2}\right)$ occurrence potential in drylands of Romania.

Considering the 16 major Romanian landforms, delimited according to the geomorphologic regionalization proposed by Posea and Badea (1984), significant spatial profile dynamics were found for both classes (Fig. 2a). While the largest 
areas with lands classified as having moderate degradation sensitivity are found in the Romanian Plain (almost $30000 \mathrm{~km}^{2}, 60 \%$ of the landform's total surface), extensive areas can also be noticed in other major landform units, such as the Moldavian Plateau ( $>8500 \mathrm{~km}^{2}, 38 \%$ of the total surface), Transylvanian Plateau and the Western Plain ( $>5000 \mathrm{~km}^{2}, 21 \%$ / 32\% of the total), Dobrogea Plateau (almost $5000 \mathrm{~km}^{2}, \sim 50 \%$ ) and the Getic Plateau (almost $4000 \mathrm{~km}^{2}, 28 \%$ ) (Fig. $3 \mathrm{a}, \mathrm{b})$. The least extensive areas can be found in the Mehedinti Plateau $\left(7 \mathrm{~km}^{2}\right)$, the Curvature $\left(155 \mathrm{~km}^{2}\right)$ and Banat $\left(203 \mathrm{~km}^{2}\right)$ Carpathians, which add up to $3 \%$ of the total surface (Fig 3a,b).

Moderate sensitivity to desertification is representative for the most extensive areas in the Romanian Plain as well (similar size to that of land degradation) (Fig. 3a). Considerable areas can also be noticed in the Moldavian Plateau (almost $6000 \mathrm{~km}^{2}, 26 \%$ of the total), Dobrogea Plateau (almost 5000 $\left.\mathrm{km}^{2}, \sim 50 \%\right)$ and the Western Plain $\left(\sim 4000 \mathrm{~km}^{2}, 25 \%\right)$, while inexistent / very small areas (of up to $5 \mathrm{~km}^{2}$ ) can be found in the Eastern, Curvature and Banat Carpathians, as well as in the Mehedinti Plateau and Crisana Hills (Fig. 3a,b).

The high degradation potential class is representative first and foremost for the Dobrogea Plateau $\left(\sim 4150 \mathrm{~km}^{2}\right.$, which corresponds to $41 \%$ of the total plateau surface), and to a lesser extent for the Romanian Plain (areas of $\sim 1500 \mathrm{~km}^{2}$ in the eastern sector which do not exceed 3\% of the plain's total area) and the Western Plain $\left(700 \mathrm{~km}^{2}, 4 \%\right)$ (Fig. 3c,d). For the most part, these areas correspond to desertification, as they almost fully overlap dry sub-humid and semi-arid climates, and absolute and percentage values of land desertification sensitivity area are almost identical to those of land degradation (Fig. 2a, Fig. 3c,d). A similar setting, in which land degradation corresponds to desertification, can also be found in the Moldavian Plateau and the Danube Delta (Fig. 2a).

Considerable spatial dynamics of the two classes are also apparent for the 41 national counties (Fig. 2b). According to the geostatistical analysis, the moderate degradation sensitivity class covers the largest area in Braila (4233 $\mathrm{km}^{2}, 88 \%$ of the total county area), followed by the counties Ialomita $\left(3865 \mathrm{~km}^{2}\right.$, $86 \%$ of the total), Galati $\left(3852 \mathrm{~km}^{2}, 87 \%\right)$, Calarasi $\left(3805 \mathrm{~km}^{2}, 77 \%\right)$, Constanta $\left(3267 \mathrm{~km}^{2}, 46 \%\right)$ etc. (Fig. 4a,b). On the opposite end, the following counties were found: Valcea $\left(72 \mathrm{~km}^{2}, 1 \%\right.$ of the total), Brasov $\left(78 \mathrm{~km}^{2}, 1 \%\right)$, Prahova $\left(128 \mathrm{~km}^{2}, 3 \%\right)$ and Covasna (166 km², 4\%) (Fig. 4a,b).

With regard to the moderate sensitivity to desertification, the first 5 highest county values (absolute, percentage) correspond to the 5 instances of land degradation, considering that the counties fully fit the dryland area category (Fig. 2b, Fig. 4a,b). At the opposite end, there are 8 cases (counties) in which land desertification sensitivity areas are non-existent (in the country's northern and central-eastern regions) (Fig. 2b, Fig. 4a, b). 


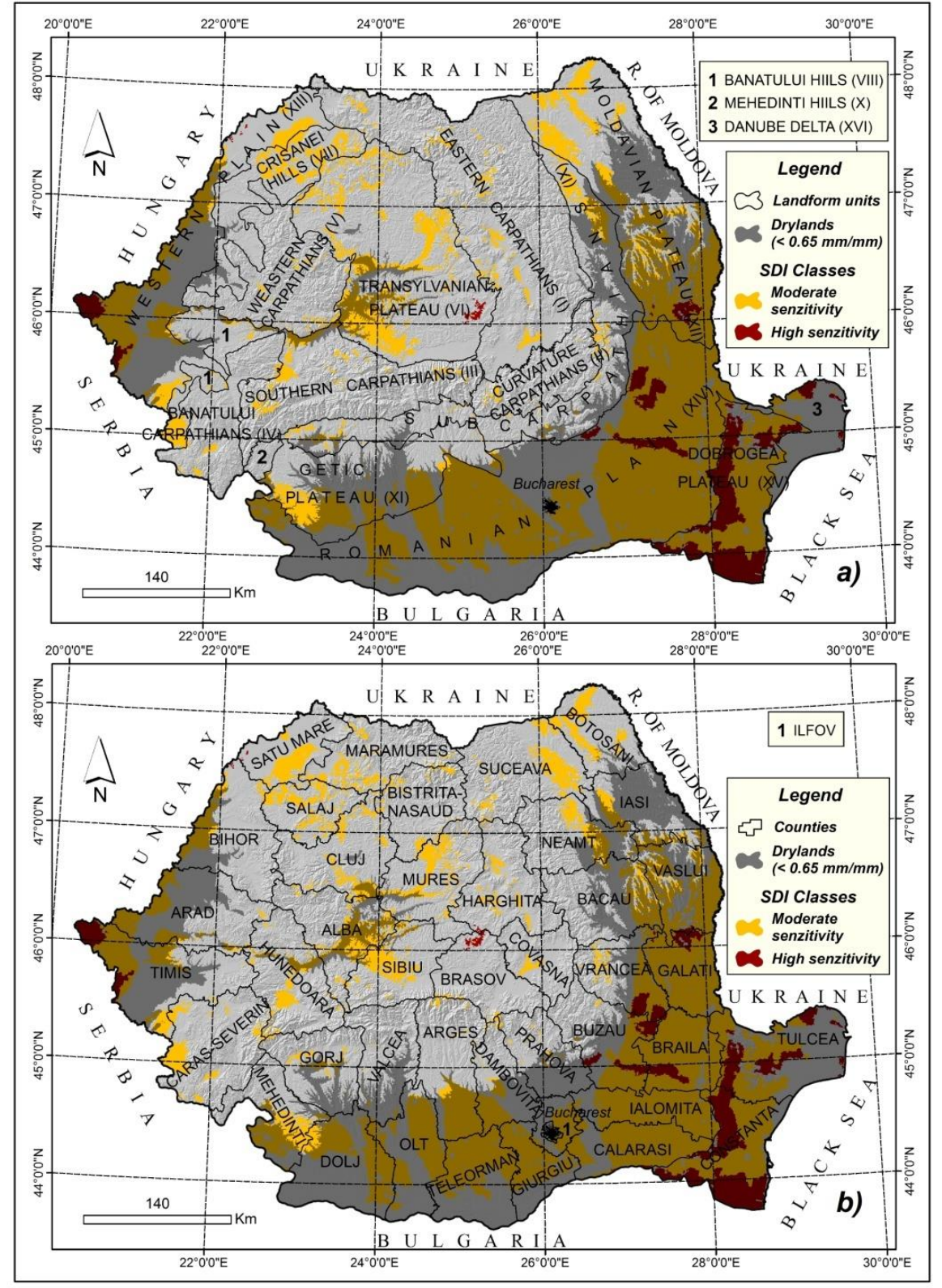

Fig. 2 Classes 3 (moderate sensitivity) and 4 (high sensitivity) of the Sensitivity

Desertification Index (SDI) represented in national landform units (a) and counties (b), highlighting the spatial relationship with dryland areas in Romania 

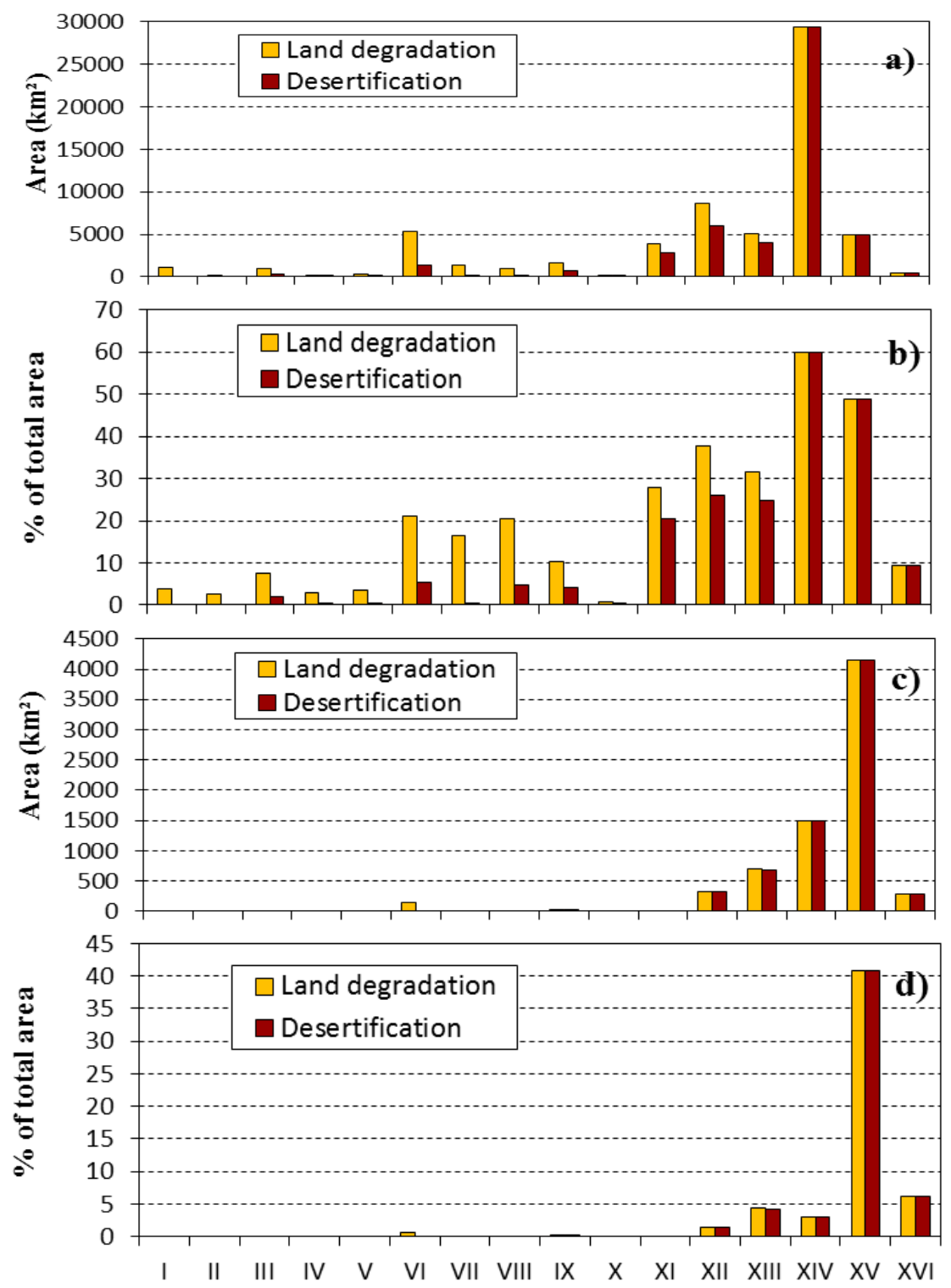

Fig. 3 Spatial dynamics and percentage of land areas with moderate $(a, b)$ and high (c, d) degradation / desertification potential, in the main landform units (I...XVI) of Romania (the data are ordered based on the geomorphological classification proposed by Posea and Badea, 1983, according to Figure 2a) 

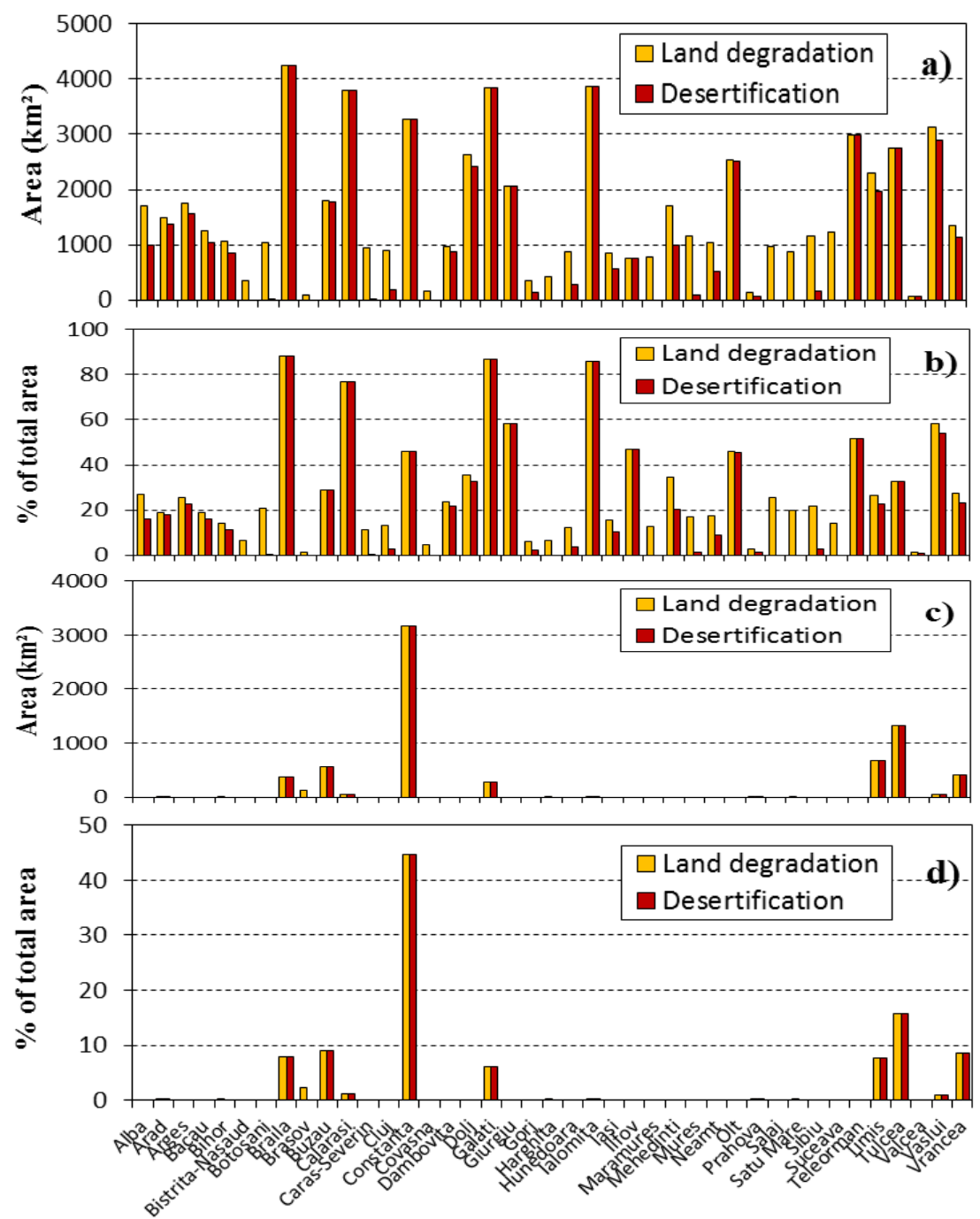

Fig. 4 Spatial dynamics and percentage of land areas with moderate (a, b) and high (c, d) degradation / desertification potential, in Romanian counties (the data are ordered alphabetically based on the counties' names)

The high land degradation potential class is found in the country's southeastern region (Constanta $-3171 \mathrm{~km}^{2}, 45 \%$ of the total area, Tulcea $-1324 \mathrm{~km}^{2}$, $16 \%$, Buzau $-558 \mathrm{~km}^{2}, 9 \%$, Vrancea $-419 \mathrm{~km}^{2}, 9 \%$, Braila $-381 \mathrm{~km}^{2}, 8 \%$ and Galati $-275 \mathrm{~km}^{2}, 6 \%$ ) and, in an isolated manner, in the west (Timis $-671 \mathrm{~km}$, $8 \%$ ) and center (Brasov $-120 \mathrm{~km}^{2}, 2 \%$ ) (Fig. 2b, Fig. 4c,d). Moreover, the 
aforementioned counties in the southeast and west have identical values for the high desertification potential as well, given that degradation class 4 overlaps dry sub-humid and semi-arid climate, typical for the 2 regions (Fig. 2b, Fig. 4c,d).

Therefore, the geostatistical analysis based on DISMED data showed that the country's extra-Carpathian regions, especially the south, southeast and east, are the most prone to degradation, when considering the potential of the fundamental natural factors. This is to be expected, seeing as two of the three quality indices are directly influenced by climate conditions (CQI, VQI) that have the highest restrictiveness (drought, aridity) in these regions of the country (Paltineanu et al., 2007; Croitoru et al., 2013; Murarescu et al., 2014; Prăvălie and Bandoc, 2015).

However, it must be mentioned that the results can be somewhat uncertain, given the shortcomings of the DISMED methodology - firstly, the low quality resolution of biophysical layers, as degradation sensitivity mapping for European states was performed at a scale of 1: 1.000.000 (EEA, 2008); secondly, there are certain methodology deficiencies with regard to the three natural indicators' details. The CQI indicator is relevant in this respect, as it was obtained solely based on the aridity index, although in other studies it is also based on other climate variables, such as Rainfall Erosivity Index (Ladisa et al., 2012).

At the same time, a major issue with DISMED results is related to the omission of socio-economic indicators (land use, land management, anthropogenic pressures), essential for the land degradation potential assessment process (Lavado Contador et al., 2009; Ladisa et al., 2012). For Romania, these variables are highly important, especially in the context of the past two and a half decades, in which land use conditions / agricultural management generally worsened (which accelerated land degradation), against the background of socioeconomic changes prompted by the political system shift after 1989. A representative example is Romania's south-western region, southern Oltenia (Prăvălie, 2013a; Prăvălie, 2013b; Prăvălie and Sîrodoev, 2013); however, while in southern regions effects are more noticeable, poor land management practices generally affected the entire national territory after 1990 .

\section{Conclusions}

The results of the extraction and quantitative analysis of the DISMED project's spatial data can be considered to be a major national reference point in terms of the overall assessment of land degradation and desertification sensitivity. Upon analysis of classes 3 (moderate potential) and 4 (high potential) of the SDI index delimited for Romanian territory, it was found that extraCarpathian areas are the most prone to degradation, especially the ones in the 
south and southeast. It was noticed that, for the most part, the degradation process in these areas corresponds to desertification, which resulted from a detailed climatic approach, based on a concrete delimitation of dryland areas in Romania, in which the land degradation process can be interpreted as equivalent to that of desertification.

However, the quantitative results must be interpreted cautiously, considering the low quality spatial data, and the fact that they are solely based on the natural criterion and do not take the fundamental anthropogenic variable into account. In Romania, this anthropogenic variable has played an essential role in determining the state of lands countrywide, especially in the last two decades, when several land management shifts were implemented, most of which accelerated the land degradation process.

To conclude, in order to obtain an integrated, complex assessment, further analyses are necessary that will target the improvement of biophysical factors which induce land degradation, and also the integration of the additional anthropogenic variable that will spatially reflect agricultural management specificities. At the same time, the integration and analysis of these components must be performed according to widely recognized methodologies, such as MEDALUS, so that the land degradation potential status in Romania to be accurately assessed, in terms of geographic reality.

AknowledgementsThe article has enjoyed the support of the "Pluri and interdisciplinarity in doctoral and postdoctoral program" cofinanced by Ministry of National Education - OIR POSDRU, contract no. POSDRU/159/1.5/S/141086.

\section{References}

Basso F., Bellotti A., Faretta S., Ferrara A., Mancino G., Pisante M., Quaranta G., Taberner M., (1999), The Agri basin. In: Kosmas, C., Kirkby, M., Geeson, N. (Eds.), The MEDALUS Project - Mediterranean Desertification and Land Use. Manual on Key Indicators of Desertification and Mapping Environmentally Sensitive Areas to Desertification, EUR 18882.

Croitoru A.E., Piticar A., Imbroane A.M., Burada D.C. (2013), Spatiotemporal distribution of aridity indices based on temperature and precipitation in the extraCarpathian regions of Romania, Theor Appl Climatol 112: 597-607.

Dregne H. E. (1976), Desertification. Symptoms of a crisis, In "Desertification, process, problems, perspectives". University of Arizona Press.

Dregne H. E. (1986), Desertification of arid lands. In "Physics of Desertification", F. ElBaz and M.H.A. Hassan (Eds.), pp. 4-34 (Dordrecht: Martinus Nijhoff).

Dregne H. E. (2002), Land degradation in the drylands, Arid Land Research and Management 16: 99-132. 
EEA (European Environment Agency), 2008, Mapping Sensitivity to Desertification (DISMED). Final Report. Version 2, Prepared by: Francisco Domingues and Jaume Fons-Esteve, ETC/LUSI. Autonomous University of Barcelona (data accessed on http://www.eea.europa.eu/data-and-maps/data/sensitivity-to-desertification-anddrought-in-europe).

Kosmas C., Ferrara A., Briassouli H., Imeson I. (1999), Methodology for mapping ESAs to desertification. In: Kosmas, C., Kirkby, M. Geeson, N. (Eds.,), The MEDALUS Project - Mediterranean Desertification and Land Use. Manual on Key Indicators of Desertification and Mapping Environmentally Sensitive Areas to desertification, EUR 18882.

Ladisa G., Todorovic M., Trisorio Liuzzi G. (2012), A GIS-based approach for desertification risk assessment in Apulia region, SE Italy, Physics and Chemistry of the Earth 49: 103-113.

Lavado Contador J.F., Schnabel S., Gomez Gutierrez A., Pulido Fernandez M. (2009), Mapping sensitivity to land degradation in Extremadura, SW Spain, Land Degr. Develop. 20 (2), 129-144.

Middleton N. J., Sternberg T. (2013), Climate hazards in drylands: A review, EarthScience Reviews 126: 48-57.

Murarescu O., Muratoreanu G., Frinculeasca M. (2014), Agrometeorological drought in the Romanian plain within the sector delimited by the valleys of the Olt and Buzău Rivers. Iran J Environ Health Sci Eng 12:152.

Paltineanu C., Mihailescu I.F., Seceleanu I., Dragota C., Vasenciuc F. (2007), Using aridity indexes to describe some climate and soil features in Eastern Europe: a Romanian case study, Theoretical and Applied Climatology 90: 263-274.

Philandras C. M., Nastos P. T., Kapsomenakis J., Douvis K. C., Tselioudis G., Zerefos C. S. (2011), Long term precipitation trends and variability within the Mediterranean region, Nat. Hazards Earth Syst. Sci. 11: 3235-3250.

Posea G., Badea L. (1984), România - unităţile de relief (regionarea geomorfologică), Hartă, scara 1:750.000, Editura Ştiinţifică şi Enciclopedică, Bucureşti.

Prăvălie R. (2013a), Aspects regarding spatial and temporal dynamic of irrigated agricultural areas from Southern Oltenia in the last two decades, Present Environment and Sustainable Development, 7 (2): 133-143.

Prăvălie R. (2013b), Considerations about the reduction of marshes in Southern Oltenia, Geographia Technica, 8 (2): 71-79.

Prăvălie R., Sîrodoev I. (2013), Land use change in Southern Oltenia in postcommunist period: evidences from Corine Land Cover, Geographica Timisiensis, 22 (1): $47-$ 56.

Prăvălie R., Bandoc G. (2015), Aridity variability in the last five decades in the Dobrogea region, Romania, Arid Land Research and Management 29(3): 265-287.

Reynolds J. F., Smith D. M. S., Lambin E. F., Turner II B. L., Mortimore M., Batterbury S. P. J., Downing T. E., Dowlatabadi H., Fernández R. J., Herrick J. E., Huber-Sannwald E., Jiang H., Leemans R., Lynam T., Maestre F. T., 
Ayarza M., Walker B. (2007), Global desertification: Building a science for dryland development, Science 316: 847-851.

Sousa P. M., Trigo R. M., Aizpurua P., Nieto R., Gimeno L., Garcia-Herrera R. (2011), Trends and extremes of drought indices throughout the 20th century in the Mediterranean, Nat. Hazards Earth Syst. Sci. 11: 33-51.

Thomas D. S. G. (1997), Science and desertification debate, J. Arid. Environ., 37: 599608.

Trabucco A., Zomer R. J. (2009), Global aridity index (global-aridity) and global potential evapo-transpiration (global-PET) geospatial database, CGIAR consortium for spatial information. Published online, CGIAR-CSI GeoPortal. Available at http://www.csi.cgiar.org.

UNCCD (The United Nations Convention to Combat Desertification). (1994), United Nations Convention to Combat Desertification in those countries experiencing serious drought and/or desertification, particularly in Africa, Paris, General Assembly of the United Nations.

Xoplaki E., González-Rouco J. F., Luterbacher J., Wanner H. (2004), Wet season Mediterranean precipitation variability: influence of large-scale dynamics and trends, Climate Dynamics 23: 63-78.

Yang X. (2010), Desertification and land degradation in arid and semi-arid regions, In: Alcantara-Ayala, I., Goudie, A. (Eds.), Geomorphological Hazards and Disaster Prevention. Cambridge University Press, Cambridge, pp. 189-198. 